\title{
ACTを基盤とした抑うつ症状および社交不安症状の重症度による拒絶に対する過敏性の状態像の 検討
}

\author{
○堀川 柚 $^{1} \cdot$ 荻島 大凱 $^{1 \#} \cdot$ 嶋田 洋徳 $^{2}$ \\ (早稲田大学 人間科学研究科 $1 \cdot$ 早稲田大学 人間科学学術院 ${ }^{2}$ ) \\ キーワード：拒絶に対する過敏性, 認知的フュージョン, 体験の回避
}

A Study of the State of Interpersonal Rejection Sensitivity by the Severity of Depression Symptoms and Social Anxiety Symptoms Based on ACT.

Yui Horikawa ${ }^{1}$, Hiroyoshi Ogishima ${ }^{1}$ and Hironori Shimada ${ }^{2}$

(Graduate School of Human Sciences, Waseda University ${ }^{1}$, Faculty of Human Sciences, Waseda University ${ }^{2}$ ) Key Words: Interpersonal Rejection Sensitivity, Cognitive Fusion, Experiential Avoidance

\section{目的}

従来から, 抑うつ症状と社交不安症状が併発すると, 臨床 的な難治を示すことが知られており（Rodebaugh et al.， 2004），このような状態像は，拒絶に対する過敏性という パーソナリティ特性を有する者が多いことが指摘されている (Downey \& Feldman, 1996)。また, 抑うつ症状および社交 不安症状に対する治療として, アクセプタンス\&コミットメ ント・セラピー（以下, ACTとする）に基づく治療の効果が高 い可能性が報告されている（Öst，2008：Arch et al.,

2012）。このようなACTの治療過程において，抑うつ症状と社 交不安症状に対しては, 事実と思考の混同状態であるとされ る「認知的フュージョン」や，不快な私的出来事と接触しよ うとせず, その形態や頻度, 文脈を変えようとする行動であ る「体験の回避」を断ち切る治療法の有効性が示唆されてい る(Cookson et al., 2019)。しかしながら, 抑うつ症状と 社交不安症状の重症度による拒絶に対する過敏性, 認知的 フュージョン，体験の回避の程度の状態像の差異に関して， 直接的に検討した研究は見受けられない。そこで本研究で は, 抑うつ症状および社交不安症状の重症度による拒絶に対 する過敏性, 認知的フュージョン, 体験の回避の程度の状態 像の差異を記述することを目的とした。

\section{方 法}

調查対象者 4 年制大学に所属する大学生および大学院生 320 名に質問紙を配布し, 回答ミスや回答漏れを除外した 262 名

（男性133名，女性109名，不明 20 名，平均年齢 $20.3 \pm 1.5$

歳）を分析対象とした（有効回答率 $81.9 \%$ ）。

調査材料 (a) 拒絶に対する過敏性 : 日本語版IPSM（巣山 他, 2014），（b）認知的フュージョン：CFQ28項目版（森本 他，2011），（c）体験の回避：AAQ-I（嶋他，2013），（d） 抑うつ症状尺度 : CES-D（島他, 1985)，（e）社交不安症状尺 度 : LSAS-J（朝倉他, 2002）を使用した。

倫理的配慮 本研究は, 早稲田大学「人を対象とする研究に
関する倫理審査委員会」の承認を得て実施された（承認番 号 : 2016-060）。なお, 本研究のデータセットの一部は, 堀 川他（2017）の報告との重複があるが, 本報告は異なる研究 目的において未発表のデータを中心に報告する。

\section{結 果}

抑うつ症状尺度および社交不安症状尺度の各下位尺度に対 してWard法による階層的クラスタ分析を行った。その結果, 4 つの解釈可能なクラスタが得られた (Figure 1, Figure 2）。第 1 クラスタは抑うつ症状および社交不安症状が低いこ とから「両低型」, 第 2 クラスタは抑うつ症状は第 1 クラス 夕と同程度であるが, 社交不安症状が第 1 クラスタよりも高 いことから「社交不安症状軽症型」, 第 3 クラスタは抑うつ 症状および社交不安症状がともに第 2 クラスタより高いため 「両中程度型」，第 4 クラスタは抑うつ症状は第 3 クラスタ と同程度であるが, 社交不安症状が第 3 クラスタよりも高い ことから,「抑うつ症状中程度 - 社交不安症状高群」と解釈 した。また, 各クラスタを独立変数, 拒絶に対する過敏性尺 度の合計得点および下位尺度, 認知的フュージョン尺度得 点, 体験の回避尺度得点を従属変数とした一元配置分散分析 を行ったところ, 全ての変数についてクラスタの主効果が有 意であり, 多重比較の結果「健常型」および「社交不安症状 軽症型」が「両中程度型」と「抑うつ症状中程度 - 社交不安 症状高群」に比べて得点が低いことが示された（Table 1)。 考 察

以上の結果から, 抑うつ症状および社交不安症状が併発し ている状態像においては, 拒絶に対する過敏性に関連するよ うな認知的フュージョンや体験の回避が生じている可能性が 高いことが考えられるため, それらを断ち切る治療法が有効 である可能性が示唆された。さらに, 抑うつ症状が一定以上 の強さで社交不安症状と併発することによって, 臨床的な難 治を示している可能性も示唆された。
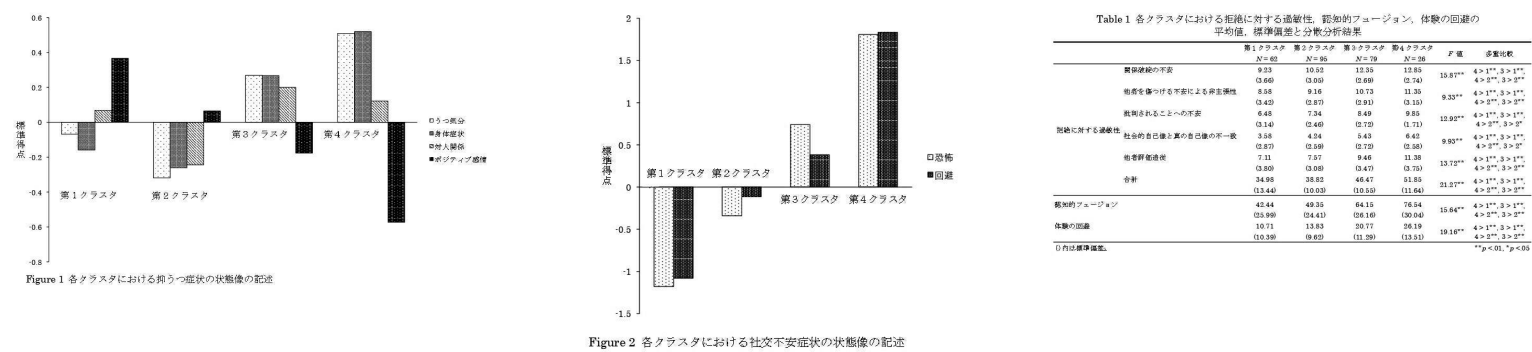